\title{
The Compatibility of State Religion and Constitutional Secularism Coexistence: Bangladesh in Context
}

\begin{abstract}
Although Bangladesh is a predominantly Muslim country, when the Constitution of Bangladesh was adopted in 1972, it embraced a pro-secular constitutional framework by adopting secularism, linguistic secular Bangalee nationalism and liberal democracy as fundamental principles. The Constitution also prohibited religion-based politics to ensure disestablishment of religion. The founding fathers of the Constitution of Bangladesh adopted this constitutional framework to circumvent recurrence of the horror of the South Asian post-colonial communal violence caused due to use of religion in politics. However, with political paradigm shifts, formal Constitutional recognition was given to Islam, establishing it as the 'state religion'. Later on, $15^{\text {th }}$ Constitutional Amendment introduced unique juxtaposition of secularism and Islam as the state religion. This article argues that the state religion clause in the Constitution which declares Islam as the state religion, is incompatible with the pro-secular constitutional framework of Bangladesh. It further argues that juxtaposition cannot be accommodated within the present constitutional framework of Bangladesh.
\end{abstract}


Can secularism and a state religion co-exist in a single Constitution? If one knows the dictionary meaning of these terms, the quick answer to that question will be no. That being said, is this question that simple to answer?

Although much of the existing literature indicate that the public sphere and public policy can be constituted by either religious or secular elements, ${ }^{1}$ the constitution of Bangladesh provides an exception through the $15^{\text {th }}$ constitutional amendment, which established secularism as a fundamental principle of the state policy, while also declaring Islam as the state religion. There are several other countries like the United Kingdom, Sweden, and Germany which are, on the one hand, secular, while on the other have established a church or official religion. But then again, there are examples of the opposite position, such as the USA, where the First Amendment ${ }^{2}$ separates the Church and the state but does not exclude religion from the public sphere totally. We also have France and Turkey who totally excluded religion from public life, applying the theory of separation of state and religion.

Therefore, it is evident that different schools of thought offer different ideas about secularism: some of them exclusionary and hostile; others inclusive and accommodating. Considering the elusive nature of secularism and taking into account the results of the competing literature, the debate on the compatibility of constitutional coexistence of secularism and state religion is at best fluid.

On the face of this fluidity, the research question in this article boils down to whether the coexistence of secularism and state religion is necessarily a binary opposite. This time, an affirmative answer to this question would be a mistake, as this article argues that such coexistence is variable and will depend on factors like policy and the public sphere.

As such, to test the compatibility in a given case, the Constitution or the legal framework in question has to be tested separately by looking into the internal factors, such as the theoretical foundation behind such coexistence, its consistency with other constituent elements of the

\footnotetext{
${ }^{1}$ Bruce Ledewitzt, 'the New New Secularism and the End of the Law of Separation of Church and state' (2009) 28 Buff Pub Int L J 1, p.26.

2 'Congress shall make no law respecting an establishment of religion, or prohibiting the free exercise thereof', Constitution of the United States, 1787, First Amendment.
} 
constitution, as well as external factors, such as socio-political and cultural elements, popular consensus and historical narratives.

This article taking Bangladesh as a test case, analyzes its external and internal factors and will argue that the state religion clause ${ }^{3}$ is, in its present form, incompatible with the pro-secular constitutional framework of Bangladesh. ${ }^{4}$ This is primarily because it contradicts principles of secularism and other fundamental tenets of the Constitution, in light of Bangladesh's past and present reality. It will also show that the scope of the state religion clause is inconsistent with the principles of political secularism. ${ }^{5}$

The article will substantiate these arguments in three parts: in part $I$, it will review and analyze the arguments of the parliament, judiciary, the Government, and the scholars in favor of the existing coexistence and highlight the limitations and discrepancies of these arguments. Secondly, part II will test the assumed compatibility through a doctrinal analysis of existing constitutional provisions, and finally part III will test compatibility in light of the different models and theories of secularism to show that the coexistence is not only inconsistent in the case of Bangladesh but also goes against basic principles of political secularism.

\section{ARGUMENTS IN FAVOR OF THE CONSTITUTIONAL FRAMEWORK CONSTITUTIVE OF THE CO-EXISTENCE OF SECULARISM AND ISLAM AS THE STATE RELIGION}

This part of the article will explore the rationales for keeping state religion with secularism. It will discuss the strength and weakness of those rationales to determine if they are justified in any way, sufficient to keep the state religion clause in the constitution. This part will complement the later parts of this article, which will analyze the relevant constitutional provisions to argue that the state religion clause is inconsistent with secular mandates of the

\footnotetext{
3 'The state religion of the Republic is Islam, but the state shall ensure equal status and equal right in the practice of the Hindu, Buddhist, Christian and other religions', Constitution of the People's Republic of Bangladesh (1972), art $2 \mathrm{~A}$.

${ }^{4}$ For the purpose of this article pro-secular constitutional framework of Bangladesh comprises principles of secularism (u/art 12 of the Constitution), Bangalee nationalism ( $\mathrm{u} /$ art 9 of the Constitution), liberal democracy (u/art 11 of the Constitution)

${ }^{5}$ Political theorist Rajeev Bhargava coined the term political secularism. However, the idea of political secularism to be discussed in this article is not based on the normative framework of political secularism discussed by Rajeev Bhargava.
} 
Constitution of Bangladesh. Before embarking on the analysis to test the compatibility of the state religion with secular mandates of the Constitution, it is necessary to see the present structure of the constitution in dispute.

The existing constitutional framework which gives rise to the controversy explored in this article starts with a verse from the Quran: bismillah-ar-rahman-ar-rahim of Sura An-Naml (27:30) of the Holy Quran. ${ }^{6}$ This verse appears before all except one of Suras of the Holy Quran. In Muslim popular culture, this verse is often used at the beginning of events and speech to show the utmost allegiance and respect to Allah (the God). However, later, the Constitution declares in Art 7 that- 'All powers in the Republic belong to the people, and their exercise on behalf of the people shall be effected only under, and by the authority of, this Constitution'.

The preamble further declares secularism as one of the high ideals of the Constitution and Art $8^{8}$ cemented the aspiration of the preamble by incorporating secularism as a fundamental principle of the state policy. Subsequently, the constitution defines secularism and freedom of religion to provide a guideline for the legislature and policy maker to understand the nature of secularism in Bangladesh. Art 12 of the Constitution collectively defined secularism and freedom of religion as:

The principle of secularism shall be realized by the elimination of (a) communalism in all its forms; (b) the granting by the state of political status in favour of any religion; (c) the abuse of religion for political purposes; (d) any discrimination against, or persecution of, persons practicing a particular religion. ${ }^{9}$

To complement the provision above, Art 41 of the Constitution stipulated that:

(a) every citizen has the right to profess, practise or propagate any religion; (b) every religious community or denomination has the right to establish, maintain and manage its religious institutions. (2) No person attending any educational institution shall be required to receive

\footnotetext{
${ }^{6}$ See, Abdullah Yusuf Ali (ed), The Holy Quran: text, translation and commentary, (Amana Corp.1983).

${ }^{7}$ supra note 3 , art 7(1).

8 "The principles of nationalism, socialism, democracy and secularism, together with the principles derived from those as set out in this Part, shall constitute the fundamental principles of state policy, ibid art 8 .

${ }^{9}$ ibid art 12.
} 
religious instruction, or to take part in or to attend any religious ceremony or worship, if that instruction, ceremony or worship relates to a religion other than his own. ${ }^{10}$

However, the secular model becomes an Islamic-secularism ${ }^{11}$ by operation of Art $2 \mathrm{~A}$ of the Constitution, which provides that: 'The state religion of the Republic is Islam, but the state shall ensure equal status and equal right in the practice of the Hindu, Buddhist, Christian and other religions'. ${ }^{2}$

Thus, this provision makes Islam 'the standard', and other religions get the equal status only when and if they get treatment similar to that of Islam. As a first position, one may argue that the existing framework is inconsistent because it includes apparently contradictory principles: secularism and an official religion. In other words, a state cannot be at the same time both secular and religious. That being said, the concept of secularism cannot be compartmentalized within a singular definitional paradigm ${ }^{13}$ Moreover, without understanding the nature of the constitution of Bangladesh, it would be a polemical argument that the existing constitutional framework is contradictory only because secularism and state religion coexist. As such, the following section will first explore the rationales for keeping the state religion with secularism within the constitution.

\section{A. Arguments in Favor of Juxtaposition of Secularism and the state Religion Clause}

The constitutional juxtaposition of the state religion clause and secularism has been adopted by the parliament and declared valid by the Supreme Court of Bangladesh. It is also strongly supported by the (democratic) government, politicians, and scholars as compatible with the overall constitutional framework.

At this point, this article scrutinizes whether or not the existing framework is consistent with the arguments provided by these actors and scholars. These arguments favoring constitutional framework are based on the following grounds:

\footnotetext{
${ }^{10}$ Constitution of the People's Republic of Bangladesh (1972) art 41.

11 This term has been introduced in this article to indicate the peculiar nature of secularism of Bangladesh which has embraced both secularism and recognized Islam as the state religion.

12 supra note 3 , art $2 \mathrm{~A}$.

${ }^{13}$ See, Gérard Bouchard and Charles Taylor, Building the Future: A Time for Reconciliation (Gouvernement du Québec 2008) 133.
} 


\section{The Constitutional Recognition under Art $2 A$ is a Reflection of the 'Social Reality' and a Way to Provide Equal Treatment to All Religions in Bangladesh}

Shared belief in a transcendental power plays a vital role in shaping a community or society. For this reason, religion and a belief system have a predominant role in constructing a new constitution or amending the old one. ${ }^{14}$ Although the constitution is the greatest example of positive law that intends to address all worldly matters, such as the establishment of government, parliament, judicial review mechanisms and ensuring citizen's rights, it also needs the people's acceptance and obedience to ensure a stable legal and social order. This acceptance could never be achieved should the constitution go against the popular belief system, traditional values, and cultural identity of the society.

Like any other society, the Bangladeshi society has always held religion in high esteem either explicitly or implicitly. Indeed, religion has played a vital role in determining the constitutional structure of Bangladesh. For the constituent assembly in 1972, determining the role of religion was a key factor. Back then, the constituent assembly unanimously agreed to build a constitution based on principles of secularism by acknowledging the past legacy of political instability and bloody communal riots. ${ }^{15}$ However, the model of secularism as adopted did not separate religion from public life as in French laicité; rather it was intended to prevent any form of preferential treatment given to a particular religion and religion-based politics. However, not censuring religion per se for the sake of protecting religious freedom later upset the balance, as evidenced by the policies of the Awami League led first Government of Bangladesh under the leadership of Shiekh Mujib, who gradually showed leniency towards his (and Bangladesh's) Muslim identity. ${ }^{16}$ Political analysis shows that, gradually AL started losing popularity for failing to ensure steady economic success, deteriorating law and order, corruption and favoritism. ${ }^{17} \mathrm{AL}$ 's secular-nationalist ideological hegemony thus needed to be substituted with stronger rhetoric. For this reason, Mujib (then President of Bangladesh), despite being a strenuous supporter of

\footnotetext{
${ }^{14}$ W Cole Durham Jr, 'Religion and the World's Constitutions' in W Cole Durham Jr et el (eds), Law, Religion, Constitution: Freedom of Religion, Equal Treatment and the Law (Ashgate Publishing Limited 2013) p.15.

${ }^{15}$ See generally Halim, Gono Parishad Bitorko (the Debate of Constituent Assembly) (CCB Foundation 2014).

${ }^{16}$ Debesh Chandra Sannal, 'Dharmanirapekhyta Samporke Bangabandhur Kichu Kotha' in Mahfuza Khanam and Topon Kumar Dey (eds), Dharmanirapekhyta:Samprodayik Sampritir Mail-Bandan (Merit Fair Prokashan 2015) p.59.

${ }^{17}$ Ali Riaz, Islamic Militancy in Bangladesh: A Complex Web (Routledge, 2008) p.9.
} 
secularism and opposed to the use of religion, started using pro-Islamic statements in his speeches (such as stating that he was proud to be Muslim and that Bangladesh is the second largest Muslim country). Mujib was also recorded to have claimed that secularism, as reflected under Art 12 of the 1972 Constitution of Bangladesh, did not imply absence of religion. ${ }^{18}$ This was the beginning of the infiltration of religion into politics. This is despite the fact that historical records and later-day political analysis notes that Mujib tried to demystify the use of secularism in national and international efforts to secure economic and political cooperation from various pro-American and Middle Eastern countries which refrained from giving recognition to Bangladesh as an independent state, which in turn affected the flow of international aid to and trade of Bangladesh. ${ }^{19}$ Thus, although prior to the assassination of Mujib (on 15 August 1975) the constitution kept its secular character, this event marked the 360-degree shift in the political culture of newly formed Bangladesh from pro-secular to pro-religious.

Three reasons for this change in trajectory can be found in the existing literature: firstly, to retain the political support of the Muslim majority; secondly, utilising the intrinsic values and religious ideals as upheld by the people; and thirdly, considering the sensitivity of the issue of religion in Bangladesh for every government since liberation to maintain a policy of avoiding any form of religious uprising. ${ }^{20}$ As such, it is argued that the "outlook and practices of Islamic ideals are blended into the lifestyle of the people of Bangladesh, in such a way that even conscious and deliberate attempts to relegate Islam to the background can have little effect". ${ }^{21}$

This view is reflected in the actions of state actors. For instance, when the Supreme Court of Bangladesh declared the constitutional amendments facilitated by the Martial Law authorities to be unconstitutional, the Cabinet of the Government recommended that the parliament reinstate

\footnotetext{
${ }^{18}$ See Ali Riaz, God Willing: The Politics of Islamism in Bangladesh (Rowman \& Littlefield Publishers Inc. 2004) p.5.

${ }^{19}$ See generally Kamal Hossain, Bangladesh: Quest for Freedom and Justice (University Press Ltd. 2013).

${ }^{20}$ The killing of the Atheist Bloggers for writing against age-old Islam dogma and the Government's reactionary response of criticizing the victims and prosecuting other bloggers for hurting religious sentiment show that the Government wanted to neutralize, if not appease, these fundamentalists and prevent any forms of popular uprising by manifesting its pro-religious position. See, 'Bloggers Killed since 2013' the Daily Star (Bangladesh) (Dhaka, 1 November 2015) <epaper.thedailystar.net/index.php?opt=view\&page=1\&date=2015-11-01> accessed 11 August 2019.

${ }^{21}$ Ahmed Shafiqul Huque and Muhammad Yeahia Akhter, 'The Ubiquity of Islam: Religion and Society in Bangladesh' (1987) 60:2 Public Affairs 200, p.225.
} 
secularism (banished by a martial law backed President General Ziaur Rahman) in the Constitution while still 'keep[ing] the provision of state religion [adopted by another martial law ruler General Ershad] [by] considering the national reality'. ${ }^{22}$ Subsequently, through the $15^{\text {th }}$ Amendment, the parliament reinstated secularism in the preamble, Art 8 and Art 12, and kept the state religion provision along with addendum: 'equal treatment to all other religions'. ${ }^{23}$

It is worth noticing that the Parliament did have the opportunity to remove all forms of religious expression imported by the Martial Law Regime, ${ }^{24}$ but they chose the easier path of concurring with the allged religious values of the people of Bangladesh, which had a vital effect on voting politics. Secondly, they had the option to promote the idea that secularism (as enshrined in Art 12) is not exclusionary to religion, which should have been self-evident.

Moreover, the present provision is said to encompass the essence of the principles of neutrality towards religion by giving equal status to all religions and, consequently, precludes any possibility of preference to any particular religion which was the case before the $15^{\text {th }}$

\footnotetext{
22 'Bangladesh moves to retain Islam as state religion' CNS News (Dhaka, 21 June 2011) $<$ http://www.cnsnews.com/news/article/bangladesh-moves-retain-islam-state-religion> accessed 16 July 2016.

${ }^{23}$ See, supra note 3 , art 8 , art 12 , and art $2 \mathrm{~A}$.

24 "Following the death of President Shiekh Mujibur Rahman in 1975, Bangladesh witnessed several coup d'états and eventually in 1976 General Ziaur Rahman (Zia) assumed power and declared Martial Law in Bangladesh. This was the turning point towards the formal introduction of religion into politics through the Constitution. To legitimize his usurpation, Zia targeted the Constitution as a means to attract the majority of Muslims of Bangladesh. In 1977, Zia amended the governing principles of the constitution and made some significant changes: the introduction of Bangladeshi nationalism in place of Bangalee nationalism to distinguish people of Bangladesh from Indian Bangalees who are mostly Hindus; replacing secularism with absolute trust and faith in Almighty Allah; defining socialism as a means to achieve economic and social justice (analogous to the social justice concept of Islam); and, finally, inserting bismillah-ar-rahman-ar-rahim on the top of the preamble of the constitution. Later, having formed his political party, the Bangladesh Nationalist Party (BNP), and becoming president by means of a rigged election, Zia removed the ban on the pro-religious, political parties through the 5th amendment to the constitution, which facilitated his alliance with pro-Islamist political parties to ensure his rule. Zia was assassinated in 1981 and succeeded by General Hossain Muhammad Ershad 1982. Ershad followed went one-step further and, for the first time, Bangladesh had a state religion (Islam) by way of the Eighth Constitutional Amendment introduced by Ershad in 1988. While Zia's measures to use Islam can be seen as a strategy to achieve legitimacy for his apparently illegitimate reign, his could not be said to be a remarkable instance of state-centric Islamization process. Nevertheless, Ershad's regime is marked by several initiatives to impose Islam on secular Bangalee culture: banning the drawing of Alpona (a kind of graffiti) in the Language Martyr's day observation because of its similarity to Hindu/Indian culture, see, Muhammad Rezaur Rahman, 'Compatibility of the state Religion Clause within a ProSecular Constitutional Framework: An Analysis in the Context of Bangladesh' (LLM thesis, McGill University 2016).
} 
Amendment. ${ }^{25}$ In 2015, the Supreme Court of Bangladesh recognized these arguments by rejecting a writ petition that challenged the constitutionality of the coexistence of secularism and state religion". ${ }^{26}$ The Court rejected the petition because the constitution ensures equal rights for people of all religions, including Hindus, Buddhists, and Christians. ${ }^{27}$ Therefore, the Court found that the juxtaposition is compatible because it does not contravene any fundamental requirements of secularism. Moreover, the Court summarily dismissed another writ petition brought by 15 citizens of the Citizens' Committee for Resisting Communalism and Autocracy, for lack of standing. ${ }^{28}$ This time, the Court did not find the arguments put to be compelling enough to entertain this petition and again cited the ground of technicalities for non-hearing.

\section{The state Religion Clause Reflects Mere Symbolic Recognition and Does not have any Overarching Effect over Principles of Secularism}

Apart from the argument of social reality, it is argued that the state religion entails only ceremonial implication and is a mere constitutional courtesy towards the diversity of religion in Bangladesh. ${ }^{29}$ This argument is based on the fact that Art 2A belongs to Part I of the constitution that describes the general features and the profile of Bangladesh: for example, the official name of the Republic, the state language, national emblem and the capital. While these provisions have intrinsic importance for describing the characteristics of the Bangladesh, (e.g. Art 1 describes Bangladesh as a unitary, independent and sovereign Republic), it is argued that they do not prevent parliament from enacting any law in light of the four core fundamental principles of the state. ${ }^{30}$ Moreover, it is further argued that Art 2A is neither part of the preamble nor part of the

\footnotetext{
${ }^{25}$ Before $15^{\text {th }}$ Amendment of the Constitution, there was no provision related to secularism and Islam was given the highest priority over other religions, ibid pp.36-37

${ }^{26}$ Rock Ronald Rozario, 'Bangladesh court ruling supporting state religion sparks criticism' UCA News.Com (Dhaka, 8 September 2015) <www.ucanews.com/news/bangladesh-court-ruling-supporting-state-religion-sparkscriticism/74224> accessed 12 August 2019.

27 ibid.

${ }^{28}$ The High Court Division of the Supreme Court of Bangladesh, on March 28, 2016, summarily dismissed a 28year-old constitutional petition challenging (revived by the aforementioned 15 petitioner) Islam as the state religion because the petitioners lacked standing to litigate without going to any formal hearing, see, Ridwanul Hoque, "Constitutional Challenge to the state Religion Status of Islam in Bangladesh: Back to Square One?" (27 May 2016), Int'l J. Const. L. Blog (blog) <www.iconnectblog.com/2016/05/islam-in-bangladesh> accessed 12 August 2019.

${ }^{29}$ S M Masum Billah, 'Can Secularism and state Religion Go Together?' (2014) 15 ELCOP YB Human Rights 32, p.44.

${ }^{30}$ supra note 3 , art 8 .
} 
fundamental principle of the state policy which is considered to be the 'guiding star' of the constitution. ${ }^{31}$ This restrains the state religion from having any overarching effect over the principle of secularism. ${ }^{32}$ Put another way: Islam being the state religion does not restrain Parliament from striking down any law (even a religious law) if it were to conflict with Art 7(2), which declares the supremacy of the constitution of Bangladesh. ${ }^{33}$ In sum, this argument states that the state religion provision only symbolically represents the numerical majority of Muslims in Bangladesh amongst other diverse religious groups.

\section{Positive Attitude to Religion Does not take Away Secular Characteristics of the State}

The argument next in line to support the state religion clause is that since secularism cannot be unequivocally defined, it has to be understood in the specific context of a particular state. Considering the social structure of Bangladesh, secularism is to be taken as a means to an end $^{34}$ and "anything that is pernicious and exploitative cannot be allowed to remain outside the control of the constitution simply because it is paraded on the garb of religion". ${ }^{35}$ In other words, just because Bangladesh has had bitter historical experience with religion does not make religion an untouchable phenomenon, hence does not justify banishing religion from the constitution. Moreover, unlike the Western understanding, secularism in Bangladesh is not based on the strict separation of religion and state, but rather on religious neutrality which implies "equal opportunity for all religions to participate in public affairs and benefit from state patronage". ${ }^{36}$ Therefore, in the context of Bangladesh, incorporation of the state religion clause only represents a positive attitude towards strengthening religious freedom.

\section{B. Limitations of the Arguments in Support of the Existing Constitutional Framework}

\footnotetext{
${ }^{31}$ Anwar Hossain Chowdhury v Bangladesh, (1989) BLD (Spl.) 1 (Supreme Court of Bangladesh) 138.

32 Secularism is declared as a high ideal by the preamble and a fundamental principle in art 8 (which is used to formulate policy of governance and as an aid to interpret any law in case of any ambiguity. See, supra note 3 , art 8 .

33 'This Constitution is, as the solemn expression of the will of the people, the supreme law of the Republic, and if any other law is inconsistent with this Constitution that other law shall, to the extent of the inconsistency, be void' supra note 3 , art 7.

${ }^{34}$ As per Billah secularism is a means to the end which is not only religious freedom and neutrality but also achieving social justice and establishing a society free from exploitation.

${ }^{35}$ supra note 29, p. 40 .

${ }^{36}$ supra 18, p. 22.
} 
The arguments forwarded above for the present constitutional juxtaposition are apparently compelling, and one with little or no grounding in the historical and socio-political situation of Bangladesh will consider them to be strong justifications for the existing framework. However, once analyzed in light of the proper historical and socio-political context of Bangladesh, the arguments lose credibility and can be found misleading due to their subjective prior assumptive nature, individualistic interpretations of constitutional law and the socialpolitical reality of Bangladesh. The limitations of the preceding arguments are discussed in the following sections.

\section{The Idea of 'Social Reality' is Superficial}

The argument that recognition of religion acknowledges the reality of socially embedded religious values and beliefs in Bangladesh is based on a presupposed assumption that religions (especially Islam) are the raison d'etre of Bangladesh, both past and present. Arguably, this assumption is inherently flawed. In the context of the South Asia, we can see the significance of religion in the community as a matter of everyday life, and any specific/special influence was found mostly within the religious communities. For that, there are no noticeable historical accounts of significant mass movements to establish an Islamic state in the territory that constitutes Bangladesh. Besides, if religion had at all built and reflected the ideology of the people, Bangladesh would not have seceded from Pakistan, a country with Islam at its core. Moreover, the declaration of secularism as a governing principle in Bangladesh had never met with any noticeable pro-religious movement. Furthermore, the allurement of establishing Islamic ideologies had been rejected by the masses in the past. For instance, the Martial Law rulers in Bangladesh did apply the strategy of attracting the majority of Muslims by adopting a proIslamic attitude, but this did not help them to sustain their undemocratic reign. ${ }^{37}$ If the strategy of establishing pro-Islamic Bangladesh was acceptable to the people, then the people would not have revolted against Martial law and demanded democratic government. ${ }^{38}$

\footnotetext{
${ }^{37}$ Martial law backed President Genral Ershad's regime is marked by several initiatives to impose Islam on secular Bangalee culture: banning the drawing of Alpona in the Language Martyr's day observation because of its similarity to Hindu/Indian culture. Ershad eventually had to relinquish his position in the face of a massive anti-autocratic movement in the 1990s.

${ }^{38}$ Sabbir Ahmed, 'Military Rule', Banglapedia <en.banglapedia.org/index.php?title=military_rule> accessed 13 July 2016.
} 
From this perspective, the social reality argument is seen to lack historical and sociopolitical support. Besides, without any empirical evidence in favor of this position, the state's argument to have a state religion clause to fulfill the people's demands is mere conjecture. In sum, the state religion clause is something which was invented, based neither on any traditional grounds nor on social necessity. Rather, it was imported to fulfill a long-term political agenda.

\section{The Idea of Symbolic Recognition and Constitutional Courtesy is Misleading}

One of the arguments for keeping the state religion clause is that it does not restrain the legislature from enacting any law that goes against the fundamental features of the constitution; hence, it is a mere symbolic recognition of religion, or a constitutional courtesy. This argument attempts to trivialize the significance of the state religion clause. In fact, as a provision within part I of the Constitution, the state religion clause is a part of the basic structure of the Constitution, that is, a provision that cannot be amended by the parliament. ${ }^{39}$ As such, even if it does not put an explicit limit on the powers of the legislature, since this clause is not amendable, one can confidently infer that the provision will in fact constitute an implied restraint on the legislature from legislating any law against this provision.

Apart from the concept of constitutional courtesy, manifesting the clause as a symbolic recognition requires scrutiny. It is true that symbolic recognition of religion in public affairs is not an alien concept, but this recognition in other countries is distinct from its status in Bangladesh. The following examples clarify this point: the presence of the name of God in constitutions (such as in Germany) and the national mottos (the national motto of the USA is "In God we Trust"), following religious ceremony in public functions, ${ }^{40}$ displaying religious symbols and state recognition of a particular church (e.g. the UK and Sweden). ${ }^{41}$

\footnotetext{
39 'Notwithstanding anything contained in [...] the Constitution... all articles of Part I [...] shall not be amendable by way of insertion, modification, substitution, repeal or by any other means.]' supra note 3 art 7B.

${ }^{40}$ supra note 1, p.7, p.17.

${ }^{41}$ Although this appears to be a difficult task, the UK and Sweden are able to achieve this balance, albeit gradually by way of significant constitutional reforms, by keeping the established church symbolic. For instance, the UK gave Christianity special legal recognition through the Church of England, but it is not an integral part of the state, it is not a recognized part of the Executive department of the state and "differential treatment of the Church of England in comparison with other churches has remained within a manageable scope", see, Winfried Brugger, 'On the Relationship between Structural Norms and Constitutional Rights in Church-state Relations' in Winfried Brugger and Michael Karayanni (eds), Religion in the Public Sphere: A Comparative Analysis of German, Israeli, American and International Law (Springer Berlin, 2007) p.22.
} 
To understand why these symbolic recognitions should be seen differently from Bangladesh, it is necessary again to go back to the history of these countries which show strong adherence of symbolic recognition without political turmoil. ${ }^{42}$ On the contrary, Bangladesh has no known historical antecedent of symbolic recognition of religion (like in the USA). When suddenly viewed from this external perspective, it becomes difficult for Bangladeshi society and concerned political actors (e.g. lawyers, parliamentarians, politicians, activists and voters) to accept that state religion is merely a symbolic notion.

Moreover, the language of the provision requires more than just a symbolic recognition, because by declaring Islam as the state religion, it represents a dual characteristic of the state (secular and religious). Heiner Bielefeldt sheds light on the paradox of this duality: 'A secular state and a religious society can harmoniously exist together. But a secular state cannot at the same time be a religious state, i.e. a state proclaiming an official state religion' ${ }^{43}$ Therefore, construing the state religion clause as a symbolic recognition is misleading, as symbolic recognitions do not significantly change the characteristics of a constitution.

\section{The State Religion Clause has an Indirect Overarching Effect on Secularism}

Secularism, as a fundamental constitutional principle, has taken seniority over the state religion clause. However, while theoretically secularism is seen to be superior to the state religion, from an applied perspective, secularism is actually subjected to the state religion clause which, as a part of the basic structure of the constitution, is not subject to amendment. This means that the legislature cannot apply a constitutional justification to uphold secularism in preference to state religion. An example of this position is the present of the anti-blasphemy provision under section 57 of the Information and Communication Technology Act 2006 (the ICT Act). The law provides that:

If any person deliberately publishes or transmits or causes to be published or transmitted in the website or in any other electronic form any material which is false and obscene and if anyone sees,

\footnotetext{
${ }^{42}$ See e.g. supra note 1, p.6.

${ }^{43}$ Heiner Bielefeldt, 'Preliminary findings of Country Visit to Bangladesh by Heiner Bielefeldt, Special Rapporteur on freedom of religion or belief', (9 September 2015) <www.askbd.org/ask/2015/09/09/preliminary-findings-byheiner-bielefeldt/> accessed 11 August 2019.
} 
hears or reads it having regard to all relevant circumstances, its effect is such [...] causes to hurt or may hurt religious belief $[\ldots]$ then this activity will be regarded as an offence. ${ }^{44}$

Although the government describes this provision as anti-hate speech legislation, the objective of such legislation is not to redress the offensive idea but is rather to restrain any possible negative outcomes that may result from such speech. ${ }^{45}$ In this context, a statement that may hurt religious sentiments does not qualify as hate speech unless such speech seeks to marginalize certain groups through vilification and detestation and may make the target group unacceptable and dangerous in the eyes of the majority of people. In this context, a secular constitution should have a mechanism for protecting religious freedom and facilitate a legal framework to prevent hate speech. However, the ICT Act 2006 punishes a person for mere criticism of religion that, under human rights law principles do not amount to hate speech. Thus, the ICT Act 2006 becomes an anti-blasphemy law which is inconsistent with the concept of secularism. ${ }^{46}$

This example shows that, although the constitution of Bangladesh is based on secularism, it actually translates into a clear preference for Islam, as criticism of other religions in Bangladesh never received equivalent state attention. As such, the concept of secularism in Bangladesh is interpreted in a way that is contrary to any other standard model applied around the world.

The following part will take the argument from here, and further it, with analytical examples to demonstrate how the present constitutional framework, with the state religion clause in it, stands in contradiction to pro-secular mandates.

\section{TESTING THE COMPATIBILITY OF THE CO-EXISTENCE OF SECULARISM AND STATE RELIGION: A THEORETICAL ANALYSIS}

\footnotetext{
${ }^{44}$ Information and Communication Technology Act 2006, s 57.

${ }^{45}$ Pearl Eliadis, Speaking Out on Human Rights: Debating Canada's Human Rights System (McGill-Queen's University Press 2014) p.231.

${ }^{46}$ Muhammad Rezaur Rahman, Influence of Religion Based Social Norms in Materializing Freedom of Expression: An Analysis in the Context of Bangladesh (Term Paper, McGill Faculty of Law 2015) [unpublished].
} 
The preceding discussion aims to uncover lacunae in the foundations of arguments based on which the parliament and the government have kept the state religion clause in the secular constitutional structure of Bangladesh. That said, one may argue that, even if there are lacunae in those arguments (as there are), the historical accounts that indicate the hidden reality do not mean that coexistence between state religion and the principle of secularism will always end in disaster. Rather, what it means is that the compatibility anaylzed by this article needs more comprehensive theoretical assessments that are sourced in these historical accounts.

Part II will embark on this assessment in two segments. In section $A$, a doctrinal analysis of the provisions related to secularism and state religion will be carried out to ascertain the inconsistencies between these principles. Section $B$ will then assess the consistency of the state religion clause with other constituent elements of the constitution. In light of the assessment, this part will argue that the state religion clause, as it appears in the constitution under Art $2 \mathrm{~A}$, is not compatible with the principle of secularism under Art 12 of the Constitution, and thus the present juxtaposition of secularism and state religion is inconsistent with the overall constitutional structure of Bangladesh.

\section{A. Incompatibility of the Present state Religion Clause (u/a 2A) with the Secularism (u/12) of the Constitution}

In the absence of extensive empirical research, ascertaining the compatibility of the questioned juxtaposition is superficial and hence non-credible. Therefore, to test the scope of the juxtaposition in a particular constitution and its resilience to state religion, an analysis of the connotations of each term and phrase is paramount. To begin with, the meaning of secularism has been defined $\mathrm{u} / \mathrm{a} 12$ of the constitution as:

The principle of secularism shall be realized by the elimination of (a) communalism in all its forms; (b) the granting by the state of political status in favour of any religion; (c) the abuse of religion for political purposes; (d) any discrimination against, or persecution of, persons practicing a particular religion. (emphasis added).

Scrutiny reveals some very important aspects of these principles: firstly, secularism is to

be realized by limiting the state from granting political status to any religion and by the elimination of "any discrimination against, or persecution of, persons practicing a particular 
religion". A plain reading of the text denying political status to any religion indicates the state's commitment to neutrality (though the provision does mention the term neutrality) regarding any religious issue. The article omits any notion of religious tolerance or explicit recognition of equal status to other religions. Rather, it adopts the classic notion of separation of religion and state, and non-interference of the state in the religious matter in governance and political affairs.

From this perspective, the way Art $2 \mathrm{~A}$ is constructed comes in direct conflict with the principle of secularism because it declares that the state religion of the Republic is Islam. This shows that a special recognition is indeed given to Islam by declaring it as the state religion. Although the provision provides for the equal status of Hindu, Buddhist, Christian and all other religions, this remains anonymous. In this way, even if the constitution directed the elimination of granting of favors to any religion and prohibited any form of political status for a religion, this would not reconcile the contradiction between the treatments of different religions.

That being said, the foregoing arguments in favor of the incompatibility may be challenged in four ways Firstly, that the concept of neutrality cannot be forcibly construed as passive in the sense that the state cannot take any positive action for religion; secondly, by giving equal status to all religions, there is no question of preferential treatment; thirdly, that declaring a state religion is not a political recognition of that religion; and finally, that the elimination of preferential treatment does not automatically entail separation of the state and religion. The following section will cement the argument that state religion is incompatible with secularism by countering these four possible critiques.

\section{Reviewing the Counter Arguments against the Arguments of Incompatibility between the} State Religion Clause and Secularism

(a) As to the first critique that that the concept of neutrality cannot be forcibly construed as passive, the following can be said. The concept of neutrality related to religion is highly debated, and there is no consensus in the existing literature as to its standard scope. Apart from the dictionary meaning of neutrality (which indicates abstention from choosing between options or arguments or ideas), the idea of neutrality in religion has at least two mutually exclusive meanings, namely: positive or benevolent neutrality (through which the state, in an attempt to 
ensure equality, maintains impartiality "specific factor and qualities in decision making" but entirely separates itself from religion), and negative neutrality (through which the state maintains impartiality with the view to reducing any religious affiliation). ${ }^{47}$ In this regard, how Bangladesh will maintain religious neutrality depends on the proper interpretation of the present constitutional arrangement. It is apparent that the government interprets religious neutrality as per Art 12 as benevolent neutrality which allows religious affiliation of the state so long as the decisions are impartial and non-prejudicial to other religious communities. Therefore, giving equal status to all religions is the proof of state neutrality. However, prominent secularists like Professor Anisuzzaman and Sirajul Islam ${ }^{48}$ argue that secularism, as reflected in Art 12, should be interpreted in its simplest sense: that the state shall not provide any political recognition to any religion. ${ }^{49}$ From their perspective, the simplest meaning of secularism is non-affiliation of the state with any religion. ${ }^{50}$ Anisuzzaman further argues that, if the founding fathers of the constitution wanted to provide equal status to all religions, then the language of Art 12 would have been quite different, so as to make such an idea compatible. ${ }^{51}$ As such, it is misleading to interpret the concept of neutrality under Art 12 as allowing any form of recognition to religion, albeit collectively.

(b) The second critique, which questions the incompatibility, by arguing that Art $2 \mathrm{~A}$ denies preferential treatment to any particular religion, also has its limitations. Once again, this article reiterates the argument that providing equal status to all religions does not amend the contradiction between Art 12(a) and Art 2A. Nevertheless, it is worthwhile to look at the analysis of the syntax, wording, and punctuation that make up the provision. This investigation reveals that Art 2A has failed to provide equal status to all religion in its true sense.

\footnotetext{
${ }^{47}$ See Rafael Palomino, 'Religion and Neutrality: Myth, Principle, and Meaning' (2011) BYUL Rev 657, 664 and 679; Robert Audi, 'Natural Reason, Natural Rights, and Governmental Neutrality Toward Religion' (2009) 4 Religion \& Human Rights 157, p.172.

${ }^{48}$ These two academics are considered as a foremost authority in the study of secularism from Bangladesh's context, politico-Islamic history of Bangladesh. They have authored many books and articles where they explained the scope of secularism and the implications of the state religion in the constitution.

49 Anisuzzaman, 'Dharmanirapekhyta Prosongay' in Mahfuza Khanam and Topon Kumar Dey (eds), Dharmanirapekhyta:Samprodayik Sampritir Mail-Bandan (Merit Fair Prokashan, 2015) p.13, p.16 and p.17.

${ }^{50}$ Sirajul Islam Chowdhury, "Rastro Hobbe Dharmanirapekho, Somaj Hobe Ehojagotik" ibid 19, p.21.

${ }^{51}$ Anisuzzaman, supra note 49, p.17.
} 
The provision starts by stating that the state religion is Islam then there is a 'comma' and 'but' followed by the state shall ensure equal status and equal right in practice; then the three (main) religions are mentioned i.e. the Hindu, Buddhist, Christian followed by 'and other religions'. The linguistic formation indicates that Islam is the state religion, and all other religions have inferior status, since 'but' as a negative conjunction indicates the disjunction between Islam and other denominations. The verb 'shall ensure' indicates a positive obligation on the state to avoid the predominance that may be created by the Islam as the state religion. Specific mention of other three main minority religions tends to indicate the second line of hierarchy through numerical percentage, as the Hinduism is the second largest religion in Bangladesh followed by Christianity. This grammatical arrangement of the article enables the state to pick and choose how to treat religions.

Had this provision intended to recognize religious pluralism, it would have clearly recognized all religions either by mentioning each one (which would be a dubious process given the diverse religious denominations followed not only by indigenous people but also Muslims, Hindus, and Christians) ${ }^{52}$ or by keeping it general. Omitting to offer protection to non-believers or agnostics has, in recent times, become a provocative question. Specifically mentioning atheism or agnosticism is not a common practice in constitutional law, however the murder of atheists in Bangladesh demonstrates the need for a resilient form of religious pluralism or nonpolitical recognition in Bangladesh. Thus, it is a plausible to argue that religious pluralism is not present in Art 12, and hence Art 2A is inconsistent by providing preferential treatment to Islam.

(c) To understand the third critique arguing that Art $2 \mathrm{~A}$ does not imply a political recognition if religion, it is important to ascertain the purpose of Art 2A. The article intends to provide a symbolic recognition to religions. However, unlike other concerned countries with constitutional recognition of state religion, the role of religion in Bangladesh, especially in public life, public discourse, and the public forum has never been symbolic historically or politically. An interesting example is a custom of the national television channel of Bangladesh (known as the Bangladesh Television) to broadcast the recital from Quran and other religious texts every day before starting transmission. It is evident that, apart from the four religions mentioned in the

\footnotetext{
${ }^{52}$ The chronology of the art $2 \mathrm{~A}$ of the Constitution is Islam (represented by 90 percent Muslim), Hindu (8.5 percent), Buddhist ( 0.7 percent), and Christian ( 0.1 percent) and rest belong to other religion.
} 
Art 2A, there is no practice of recitation of other religious scriptures. Had such recital been symbolic, then there would have been no reason to recite The Quran everyday. One can here see a clear pattern of preferential practice to put Islam in a revered position.

As such, in the presence of clear provisions to protect religious freedom and in the absence of any such historical practice in favor of symbolic recognition of religion in the constitution, it is difficult to refute the political nature and implication of the state religion clause.

(d) The following response can be given to the final point of critique, being that the constitution implies a separation of religion and state, but there is no explicit indication regarding such separation. While this argument has its merit, it is also true that Art 12 talks about the elimination of abuse of religion for political purposes, a goal which cannot be achieved unless the state maintains some form of separation from religion. In other words, if the state, instead of maintaining distance from religion, starts promoting all religions, then there will be a question of priority among the religions. For example, if the state decided to fund an Islamic institution, then the people from other religions might question the state's motive which would in turn lead to a political movement based on religion. Therefore, if the state wants to ensure the first two principles of secularism under Art 12, then it has to maintain some forms of distance if not strict separation from religions. ${ }^{53}$

In sum, the above discussion shows that there is a clear inconsistency between the state religion clause $\mathrm{u} / \mathrm{a} 2 \mathrm{~A}$ and the provision of secularism $\mathrm{u} / \mathrm{a} 12$. From this point, this article, in the following section will further its assessment of the compatibility of the state religion clause by looking into other components of the constitution which, together with secularism, form the prosecular constitutional framework.

\footnotetext{
${ }^{53}$ The strict separation sometimes requires the state to ignore some of the social functionality of the religion like religious festival or ceremonies. In the context of Bangladesh, while it is better to avoid promoting religion but since it is liberal towards religious freedom, thus the state shall have to ensure that its action is not hindering the observation of these festivals or ceremonies.
} 


\section{B. Contradictions between the state Religion Clause and the Fundamental Principles of the State Policy of the Bangladesh Constitution}

The preamble of the constitution of Bangladesh enunciates "nationalism, socialism, democracy and secularism" as four high ideals. Art 8 follows suit by incorporating these high ideals as the core fundamental principles and affirms that: 'these principles shall [...] be applied by the state in the making of laws, shall be a guide to the interpretation of the constitution and of the other laws of Bangladesh, and shall form the basis of the work of the state and of its citizen'. ${ }^{54}$

Although these principles are not judicially enforceable, ${ }^{55}$ it is apparent that they form the foundation of the constitution. As such, the constitutionality of any law shall be determined in light of these principles. Hence, to test the consistency of the state religion clause, recourse must be had to these principles. In addition to the earlier discussions on secularism, this part will argue that state religion is also contradictory to the core principles of Bangalee nationalism and liberal democracy.

\section{The Point of Contradiction between the State Religion Clause and Bangalee Nationalism}

An understanding of nationalism is vital to comprehend the emergence of Bangladesh as a nation state in 1971. Nationalism played a pivotal role in the liberation war against Pakistan in 1971. Bangalee nationalism defined its people, their identity and the unique characteristics which separate Bangladesh from both Pakistan and India (the Indian Bangalees). Along with the economic and political subjugation by the West Pakistan regime, the refusal to recognize the distinct culture and language of East Pakistan, with the superimposition of Islamic identity, contributed to Bangladesh's secession. ${ }^{56}$

A reader not familiar with the geopolitical antecedents of South Asia might wonder why the recognition of regional identity was refused in the first place. The refusal of the unique identity of East Pakistan was driven by the prejudice that Bengali language and culture were an offshoot of Indian Hindu culture and hence were anti-Islamic. However, for the people of East Pakistan, being Bangalee "was not a mere illusion or frivolous idiosyncrasy, but has a definite

\footnotetext{
${ }^{54}$ supra note 3 , art 8 .

55 ibid.

${ }^{56}$ Sanjay K Bhardwaj, 'Contesting Identities in Bangladesh: A Study of Secular and Religious Frontiers' Asia Research Centre Working Paper No 36, p.14.
} 
character which separated them from other races in Pakistan". ${ }^{57}$ Moreover, most of the population was not prepared for losing their identity in favour of an imposed Islamic national identity. As a result, Bangalee nationalism became a vital force to unify the people of the East against the Pakistanis since 1948 and more strongly since the Language Movement of 1952. In the post-independence era, Bangalee nationalism as a fundamental constitutional principle has gained more prominence. Art 9 of the constitution of 1972 and the present constitution ${ }^{58}$ defines Bengalee nationalism as: 'the unity and solidarity of the Bangalee nation, which, deriving its identity from its language and culture, attained sovereign and independent Bangladesh through a united and determined struggle in the war of independence, shall be the basis of Bangalee nationalism'. ${ }^{59}$

Two main features of this nationalism are language and the war of independence in 1971 which reflects movements against religious hegemony (especially hegemony through Islam). These developments show that people of Bangladesh as a nation shall be united based on their shared language and culture, rather than religion. This makes Bangalee nationalism more culture-centric than religious. As such, incorporation of any provision that ensures special recognition to religion makes it inconsistent with Bangalee nationalism.

There can be questions from an historical perspective that a language and culture based nationalism does not have to automatically conflict with religion, especially when religion (both Islam and Hinduism) formed an integral part of Bangalee life. Bangali [Bangalee] Mussalman has been a popular term for a long time in the territory that became Bangladesh, having sociocultural and religious significance. ${ }^{60}$ However, post-1971 history shows that many quarters equated Bangalee identity with anti-Islamic identity. Ziaur Rahman replaced Bangalee nationalism with Bangladeshi nationalism to distinguish people of Bangladesh from Indian Bangalees. ${ }^{61}$ However, drawing a distinction between Bangladesh and India was not Zia's only

\footnotetext{
${ }^{57}$ Khondker Delwar Hossain v Bangladesh Italian Marble Works and Others (2010) 62 DLR (AD) 298 (Supreme Court of Bangladesh) para. 117.

${ }^{58}$ This article was omitted together with secularism by the constitutional Fifth Amendment in 1979. However, both of these articles were reinstated in 2011 by Fifteenth Amendment after the Fifth Amendment was declared unconstitutional by the Supreme Court of Bangladesh, see, supra note, 57, p.149.

${ }^{59}$ supra note 3 , art 9.

${ }^{60}$ Ahmed Chhofa, Prabandha Samagra [An Anthology], vol 1 (Howlader Prokashoni 2014) 40 [translated by the author].

${ }^{61}$ See generally, Marcus Franda, 'Ziaur Rahman and Bangladeshi Nationalism' (1981) 16:10/12 Economic \& Political Weekly p.357.
} 
motive. Rather, Bangladeshi nationalism was necessary for his Islamization scheme: he also omitted secularism from the constitution and introduced a new provision, which introduced 'absolute trust and faith in Almighty Allah' as a fundamental principle of the constitution. ${ }^{62}$ These simultaneous changes indicate that Bangalee nationalism could have been complementary to secularism but was not compatible with the superiority of God as perceived in (orthodox) Islam. From this perspective, recognizing Islam as the state religion means facilitating an identity conundrum, i.e. whether the people of Bangladesh are first Muslim, and then Bangalee, or Bangladeshis who are Muslims. In this struggle between nationalism and religious identity, the vision of unity and solidarity forged by secular elements were compromised. Hence, finally, prosecular nationalism in the Constitution became meaningless.

\section{The State Religion Clause is Incompatible with Liberal Democracy under the Constitution of Bangladesh}

Democracy, another basic tenet, found in Art 11 of the constitution is based on the liberal democracy model. ${ }^{63}$ To ensure the basic pillars of liberal democracy, any elements that facilitate majority domination have to be eradicated. From the liberal democratic perspective, promoting religion is one of the ways to prejudice individual freedom and equal representation. Hence, it is necessary to separate religion from the state. This indicates that a constitutional provision for a liberal democratic system must maintain neutrality towards religion; a task in which secularism plays a vital role. Although the Constitution of Bangladesh incorporates secularism to facilitate the effectiveness of democracy, the concurrent presence of state religion makes both democracy and secularism dysfunctional.

However, in contrast, it is argued that promoting religion is not contradictory to liberal democracy and construing liberal democracy as secular per se is misleading. ${ }^{64}$ In this regard, Will Kymlicka argues that, "liberal neutrality actually allows the state to promote a particular religion on the same terms that it does a particular language- namely, as long as it is done for

\footnotetext{
${ }^{62}$ supra note 57, p.107.

${ }^{63}$ It stipulates that the "Republic shall be a democracy in which fundamental human rights and freedom and respect for the dignity and worth of the human person shall be guaranteed and in which effective participation by the people through their elected representatives in administration at all levels shall be ensured.", see, supra note 3, art 11.

${ }^{64}$ Veit Bader, 'Secularism, Public Reason or Moderately Agnostic Democracy?' in Geoffrey Brahm Levey and Tariq Modood (eds), Secularism, Religion and Multicultural Citizenship (CUP 2009) p.111.
} 
some neutral reason, such as social harmony or communication". ${ }^{65}$ Such arguments offer liberal democracy scope to promote or accommodate religion for ensuring social harmony. In this context, the question again boils down to Bangladeshi reality: has the recognition of state religion ever succeeded in securing social harmony in Bangladesh? In a country with 90 percent Muslim population, a separate recognition of Islam is not a necessity, but rather a hegemonic tool. This recognition has, over the years, facilitated the existence of oxymoronic complexes: democracy and theocracy now compete for primacy in a 'secular' Bangladesh. Therefore, the provision of a state religion is also contradictory to the constitutional principle of democracy.

To conclude, part II has shown the reasons the state religion clause in its present form is incompatible with the principles of secularism, nationalism, and democracy. The discussion makes it clear that, as long as the state religion clause remains in the constitution, the effectiveness of other basic principles that forms the pro-secular constitutional framework will be compromised.

In the following section, this article will show that the incompatibility of the state religion is not entirely sui generis to Bangladesh. It will explore the principles of political secularism and different models of secularism. This section will be the final argument that will establish the incompatibility of the state religion clause by showing that, even under explicitly accommodating models of secularism, the recognition of religion(s) as is done in Bangladesh cannot be accommodated.

\section{COMPATIBILITY OF STATE RELIGION WITH THE EXISTING THEORIES AND MODELS OF SECULARISM}

The existing literature on the concept of secularism has not been aligned in a single normative framework. The concept is ever expanding and exceedingly dynamic and thus it is difficult to construct a single definition. For that reason, a scholar like Charles Taylor has observed that "it is not entirely clear what is meant by secularism" ${ }^{66}$ However, the reason behind this complexity is not that the concept is confusing; rather that it expands its components in a different manner in different contexts and disciplines. Therefore, each attempt to explain the

\footnotetext{
${ }^{65}$ Geoffrey Brahm Levey, 'Secularism and Religion in a Multicultural Age', ibid 6.

${ }^{66}$ Nader Hashemi, Islam, Secularism, and Liberal Democracy: Toward a Democratic Theory for Muslim Societies (OUP 2009) p.105.
} 
state-religion relationship concerning secularism faces a counter question asking what is the notion of secularism that is being referred to. For this reason, it is first necessary to explore the current understandings of secularism and then follow up by ascertaining the proper definition that can be applied in Bangladesh's case. This will in turn help to construct the theoretical framework to be used for assessing the compatibility of state religion in a secular constitution.

Three major disciplines of the social sciences: philosophy, sociology, and political science, all have interpreted secularism in different ways. These interpretations constitute dominant explanations of the phenomenon. ${ }^{67}$ Nader Hashemi explains it in following way:

Philosophically, it can be described as rejection of the transcendental and metaphysical in favor of the existential and empirical; sociologically, the term entails the gradual decline of religion's influence on public life and social institutions; and politically, it is seen as the separation between private and public spheres, represented by the separation of state and religion. ${ }^{68}$

For the present case, the two basic features of secularism in the constitution of Bangladesh relate to the elimination of abuse of religion for political purposes. As such, secularism, as enshrined in the constitution, can be considered to be a political philosophy that delineates the relationship between religion and the state. ${ }^{69}$ As such, secularism from the political science perspective (which focuses on the state-religion relationship) is the appropriate approach for the following discussion. This definition will inform the discussion as to whether a state religion can be accommodated within the purview of political secularism. For this article, secularism in a political sense shall be termed as 'political secularism'.

\section{A. The Key Principle of Political Secularism and its Purview}

Over the years, different formulas of secularism have been propounded which include: 'the separation of Church and state', 'state neutrality towards religions' or 'the removal of religion from public space' to draw the line between religion and state. ${ }^{70}$ As mentioned above, in

\footnotetext{
${ }^{67}$ Ali Riaz, 'The Future of Secularism' < kathakata.com/archives/1755> accessed 11 June 2016.

${ }^{68}$ supra note 66, p. 106.

${ }^{69}$ The reason, the secularism in Bangladesh is to be considered as a political philosophy because the objective of secularism is to find the best way to govern complex, religiously pluralistic society, see, Jacques Berlinerblau, how to be Secular: A Call to Arms for Religious Freedom (Houghton Mifflin Harcourt, 2012) p.5.

${ }^{70}$ supra note 13 , p. 135.
} 
the absence of an unequivocal framework for secularism, these ideas each "contain part of the truth", ${ }^{71}$ and collectively provide key principles which construe the complex definition of secularism. According to Maclure and Taylor, secularism entails two prevalent principles which are equality of respect (recognizing equal moral value or dignity of all citizens) and freedom of conscience. ${ }^{72}$ These two principles can be achieved by applying two operative modes: by ensuring the neutrality of the state towards religion, and separation of church and state (or, as the case may be, a separation of state and religion). ${ }^{73}$ Although these operative modes may be different, they are interrelated in the sense that the state cannot ensure neutrality without some operative separation between religion and state. That being said, the threshold of separation might vary in different countries. While some countries separate the two by excluding religion from the public sphere altogether, others, instead of pushing it to the private sphere, maintain an equal distance from anything that could be defined as religion Ahmet T. Kuru termed the restrictive model of secularism as assertive secularism, while the flexible one as passive secularism. ${ }^{74}$

Irrespective of their differences, these different models of secularism depend on how far a state will allow religion in the public sphere. For instance, France with its model of secularism (laicité) reduces the public influences of religion by prohibiting all forms of religious symbols or dress that may indicate difference among citizens. ${ }^{75}$ On the other hand, countries like the USA, by the First Amendment of the Constitution, maintain a different degree of separation between church and state, which is realized not by excluding religion from of the public sphere. Again, Indian secularism, which is slightly different from the French and the US models, is based on a principled distance between religion and state (instead of separation). This model provides that "religion may intervene in the affairs of the state if such intervention promotes freedom, equality or any other value integral to secularism". ${ }^{76}$ This implies that state can interact with religion so long as the state is not promoting a religion and the religious institutions are not interfering with

\footnotetext{
${ }^{71}$ ibid.

72 Jocelyn Maclure \& Charles Taylor, Secularism and Freedom of Conscience (HUP 2011) p.20.

73 ibid.

${ }^{74}$ Ahmet T Kuru, Secularism and State Policies Toward Religion: The United States, France, and Turkey (CUP 2009) p.11.

${ }^{75}$ ibid p.124.

${ }^{76}$ Rajeev Bhargava, 'Political Secularism: why it is needed and what can be learnt from its Indian version”, supra note 64, p.104.
} 
state actions. Rajeev Bhargava termed this version of secularism as 'contextual secularism', where the state and religion need not be mutually exclusive, but where religious and political institutions shall maintain non-sectarian separation. ${ }^{77}$

\section{Can Political Secularism Accommodate a state Religion Clause Like in Bangladesh?}

The abovementioned discussion makes it apparent that the degree of separation between state and religion may vary according to the context and socio-political differences. However, under political secularism, the state has to ensure distance or neutrality from religion to ensure the basic principles of secularism. For that reason, political secularism may allow public visibility of religion or even the state's interaction with religion, but that interaction is to protect freedom of thought, conscience and religion, and not to promote a faith system. This leads to the inference that the state religion clause under the constitution of Bangladesh is beyond the purview of accommodating state religion under political secularism which is thought to be the foundation of Art 12.

\section{CONCLUSION}

This article began by asking whether secularism and state religion could coexist in a constitution. In exploring this issue, it looked into the constitutional paradox of Bangladesh, created in the year 2011. The article analyzed how compatibility between secularism and a state religion in the constitution is impossible because it stands in direct contradiction with secularism, liberal democracy, and nationalism: three basic constituent principles of the constitution of Bangladesh.

The article further substantiated the argument of incompatibility by exploring the principles of political secularism and reviewing different models of secularism to show that, even under an explicitly accommodating model of secularism (like in the USA or India), no model allows the promotion of religion/religions by the state as is done in Bangladesh.

Finally, the article also reviewed the arguments of state actors and scholars favoring the maintenance of the state religion clause in the constitution and argued that there are

\footnotetext{
${ }^{77}$ Rajeev Bhargava, 'What is Secularism for?' in Rajeev Bhargava (ed), Secularism and its Critics (OUP 1998) p.536.
} 
discrepancies in these arguments based on the integration of the state religion clause into the secular constitutional structure of Bangladesh. With these discrepancies, the claim of state actors and scholars as to the compatibility of said coexistence become vulnerable. 